Рекомендована д. фрармац. наук, профр. О. М. Заліською

УДК 615.015+616-085+616.61-008.6.

DOI

\title{
КЛІНІКО-ЕКОНОМІЧНИЙ АНАЛІЗ ЗАМІСНОЇ ТА ФАРМАКОТЕРАПІЇ ХВОРИХ НА ХРОНІЧНУ ХВОРОБУ НИРОК V СТАДІї
}

\author{
() І. О. Федяк ${ }^{1}$, Н. В. Шолойко ${ }^{2}$ В. О. Ворох ${ }^{1}$ \\ ${ }^{1}$ /вано-Франківський національний медичний університет \\ ${ }^{2}$ Національний медичний університет імені О. О. Богомольця
}

\begin{abstract}
Резюме: розглянуто проблему фрінансування гемодіалізу для хворих в Україні і представлено кількісні показники ії вирішення в Івано-Франківській області - регіоні, який є лідером рейтингу щодо лікування хворих замісними методами ниркової терапії. Окрім того, подано результати ретроспективного клініко-економічного аналізу супутньої фрармакотерапії хворих на хронічну ниркову недостатність, які перебували у відділенні хронодіалізу Обласної клінічної лікарні м. Івано-Франківська. За даними дослідження, пацієнти, окрім сеансів гемодіалізу та перитонеального діалізу, отримали медикаментозне лікування ускладнень хронічної хвороби нирок (анемії, артеріальної гіпертензії, порушення фросфорно-кальцієвого обміну), а також лікування супутніх хвороб, що потребує корекції відносно відповідності вимогам Клінічних протоколів.
\end{abstract}

Ключові слова: хронічна хвороба нирок, фрінансування гемодіалізу, клініко-економічний аналіз.

Вступ. Упродовж останніх десятиліть спостерігається значне збільшення розповсюдження хвороб нирок: інфекцій сечовивідних шляхів, хронічного пієлонефриту, вторинних нефропатій (особливо зумовлених цукровим діабетом I і II типів). Ці хвороби є одними $з$ факторів ризику зростання серцево-судинної смертності [1]. На даний час налічується близько 450 тис. співвітчизників із хронічними хворобами нирок (XXH), з яких близько 20 тис. потребують проведення гемодіалізу [2]. При XXH гемодіаліз проводять, коли ниркова недостатність не піддається консервативній терапії та переходить у термінальну стадію. Окрім гемодіалізу, при якому хворі залежать від апарату «штучної нирки», - екстракорпорального методу очищення крові, існує перитонеальний діаліз (інтракорпоральний метод). Але він має обмежене застосування [3, 4].

У розвинених країнах інтегроване лікування дає змогу продовжити життя хворим 3 недіабетичним ураженням нирок у середньому на 20-25 років, 3 діабетичним - на 12-15. Середній вік пацієнтів на діалізі в Європі - 64 роки, до $20 \%$ таких хворих мають вік понад 75 років. В Україні середній вік пацієнта на діалізі - 42 роки [5]. У 2014 р. потреби одного хворого співвітчизника, пов'язані 3 гемодіалізом, оцінювали від 170 до 190 тис. грн на рік. Але існуюча система фрінансування надання медико-фрармацевтичної допомоги пацієнтам нефррологічного профрілю не здатна забезпечити ії належний рівень $[2,5,6]$.

Аналіз даних літератури показу, що доступність допомоги хворим 3 ураженням нирок в Україні $€$ вкрай низькою, порівняно з країнами ЄС та США, через від- сутність необхідного медичного обладнання, високу вартість витратних матеріалів, лікарських засобів (Л3), виробів медичного призначення (ВМП) [6].

Відповідно до Бюджетного Кодексу, МО3 України здійснює державні закупівлі Лз і ВМП виключно на виконання Загальнодержавних цільових програм, а забезпечення хворих із XXH матеріалами для гемодіалізу здійснюється за кошти місцевих бюджетів, які не покривають усіх витрат, а регіональні відмінності становлять від 20 до 80 \% [2]. Але, окрім фрінансування матеріалів для обслуговування апаратів «штучної нирки», хворі на гемодіалізі повинні отримувати супутню терапію відповідно до Протоколу лікування пацієнтів з XXH V стадії: діагностика стану та корекція порушень фосорорно-кальцієвого обміну у хворих, які лікуються методом гемодіалізу та Протоколу лікування пацієнтів з XXH V стадії: лікування анемії (Протоколи) $[4,7,8]$.

Серед областей України Прикарпаття займає передові позиції щодо лікування хворих замісними методами ниркової терапії. Тут фрункціонує 8 відділень гемодіалізу $[2,6,9]$. Тому метою даної роботи став аналіз показників фрінансування гемодіалізу для пацієнтів із XXH V стадії у розрізі областей, а також клініко-економічна оцінка супутньої фрармакотерапії пацієнтів із хронічною нирковою недостатністю в Івано-Франківській області.

Методи дослідження. Особливості фрінансування гемодіалізу на Прикарпатті вивчено шляхом аналізу доступних джерел літератури та інтерв'ювань в динаміці років завідувача відділення хронодіалізу Обласної клінічної лікарні м. Івано-Франківська Олега

ISSN 2312-0967. Фармацевтичний часопис. 2015. № 4 
Легуна. На першому етапі ретроспективного клінікоекономічного аналізу (КЕА) був проведений аналіз пацієнтів із гострою і хронічною нирковою недостатністю. Для цього 3 архіву зазначеного лікувальнопрофрілактичного закладу було відібрано 74 медичні картки стаціонарних хворих 3 діапазоном діагнозів N.71 - N.19, які перебували на лікуванні у відділенні хронодіалізу у 2014 році. За листками призначень пацієнтів здійснено інтегрований частотний / ABC / VEN-аналіз.

Результати й обговорення. На першому етапі дослідження за даними відкритих джерел було вивчено проблеми фрінансування гемодіалізу в Україні загалом і на Прикарпатті зокрема. На даний час визначення обсягів асигнувань для закупівлі лЗ та ВМП для хворих нефрологічного профрілю здійснюється відповідними місцевими органами виконавчої влади в процесі фрормування і виконання власних бюджетів. Тому у нас показник забезпеченості замісними методами ниркової терапії значно відрізняється за областями $[2,4,6,9]$.

У 2012 р. забезпеченість у проведенні гемодіалізу хворих на XXН становила 10,1 пацієнт на 100 тисяч населення. Найвищим зазначений показник був в Івано-Франківській області - 24,6 пацієнтів на 100 тис. населення, найнижчим - у Луганській 4,9 [9]. У 2013 р. цей показник по Україні становив 15,9 на 100 тис. населення (лідером традиційно була Івано-Франківська область - 32 особи, аутсайдером - Луганська з показником 8,3 особи на 100 тис. населення відповідно) [5].

Для порівняння, забезпечення населення Європи замісною нирковою терапією за 2012 р. була в середньому 450 на 100 тис. осіб: найвищий показник був у Великобританії - 650, найнижчий - у Румунії - 50 на 100 тис. осіб [5].

На початку 2013 р. в Україні програмний гемодіаліз отримувало 4952 пацієнти, 877 хворих лікувалося перитонеальним діалізом, 840 осіб жили 3 трансплантованою ниркою - це лише 15-20 \% від усіх пацієнтів, які потребують такого лікування [5, 6, 9].

У документі «Медико-демографічна ситуація та основні показники медичної допомоги населенню в регіональному аспекті, 2013 рік», який був виданий у 2014 році, лише 5 областей представили бюджет подолання проблеми хворих на XXH V стадії. А саме: Івано-Франківська область у 2013 р. витратила на матеріали для гемодіалізу, перитонеального діалізу, імуносупресанти 24 614,6 тис. грн; Одеська область подала дані витрат на проведення гемодіалізу за 2011 рік (24 430 тис. грн); Харківська область показала вартість централізованої закупівлі витратних матеріалів лише для перитонеального діалізу (1 523,1 тис. грн); Хмельницька область роздільно представила витрати на гемодіаліз (12 000 тис. грн) та перитонеальний діаліз (5 200 тис. грн); Чернігівська область представила потребу на 2014 рік, яку оцінила у 29500 тис. грн та зазначила, що у 2010 р. області була надана субвенція з Державного бюджету для лікування хворих з нирковою недостатністю у сумі 17100 тис. грн. Інші області не подали даних [10].

Отже, окрім Національного реєстру хворих на XXH [9], і це джерело [10] підтвердило, що найвища забезпеченість у проведенні гемодіалізу хворих на XXH серед областей України є у Івано-Франківській області.

Упродовж 2013 р. на Прикарпатті сеанси гемодіалізу були проведені 327 пацієнтам, 8 осіб перебували на перитонеальному діалізі, а 19-м - була проведена операція з трансплантації нирок. Загальна кількість хворих склала 364 особи, що становило на 1 млн населення за замісною нирковою терапією всього 263,4 пацієнта: на гемодіалізі - 236,6 осіб (89,8 \%,); перитонеальному діалізі - 13,0 (4,9\%); $з$ трансплантацією нирки - 13,7 (5,2 \%). У 2014 р. загальна кількість прикарпатців, які перебували на замісній нирковій гемодіалізній терапії, становила 391 осіб, з яких на 01.01.2015 р. залишилося 337 пацієнтів (різницю становлять померлі і особи, які вибули з області). У 2015 р. екстракорпоральний метод очищення крові в Івано-Франківській області приймали загалом 375 хворих, а на 01.10.2015 року їх було 338 осіб.

Івано-Франківська облдержадміністрація прийняла комплексну програму «Здоров'я населення Прикарпаття на 2013-2020 роки», відповідно до якої виконуються заходи для уникнення зупинки діалізних центрів. Вартість проведення одного сеансу гемодіалізу у 2013 початку 2014 рр. становила, за словами завідувача відділення хронодіалізу, близько 1000 грн. У 2014 р. додатково було виділено ще 14 млн грн для компенсації вартості розхідних матеріалів. Оскільки до умов договору 3 постачальником згідно з положенням ч. 5 ст. 40 Закону України «Про здійснення державних закупівель» включено підстави щодо збільшення ціни договору про закупівлю з урахуванням зміни курсу валют. Законом України «Про запобігання фінансової катастрофи та створення передумов для економічного зростання в Україні» від 27.03.2014 № 1161-VII внесено зміни у Податковий Кодекс України: вилучено п. 197.1.27, яким встановлювалося звільнення від оподаткування податком на додану вартість (ПДВ) ЛЗ та ВМП і, починаючи 3 01.04.2014 р., на лЗ та ВМП за переліком встановлено ПДВ $7 \%$ [11].

Окрім цього, станом на 01.10.2015 р. у 3 рази зріс курс американської валюти щодо гривні, що призвело до значного збільшення вартості Лз і витратних матеріалів. За нашими розрахунками, ринкова вартість ЛЗ зросла у 3,5 раза, а вартість розхідних матеріалів для проведення гемодіалізу, яку закладали у бюджети різних областей у 2015 р. 1 500-1 800 грн. Тому для забезпечення у середньому 357 прикарпатців гемодіалізом у 2015 році місцеві бюджетні асигнування повинні становити близько 90 млн грн. Вод-

ISSN 2312-0967. Pharmaceutical review. 2015. № 4 
ночас обсяг коштів обласного бюджету, спрямований на реалізацію регіональних програм, затверджених рішенням обласної ради на 2015 рік за галуззю «охорона здоров'я», передбачався у розмірі 90,3 млн грн [12]. Якщо вартість витратних матеріалів на 2016 рік зросте пропорційно до курсу національної валюти, то у бюджеті Івано-Франківської області на 2016 рік для забезпечення 338 пацієнтів (особи, які знаходяться на гемодіалізі з 01.10.2015 р.) необхідно передбачити вже 146 млн грн. А це - 1/4 усіх видатків на охорону здоров'я області.

Однак, окрім обласного бюджету, сукупне фрінансування допомоги хворим на XXН включає кошти районних та міських бюджетів і небюджетних джерел. Так, ресурсне забезпечення Регіональної програми надання медичної допомоги хворим нефрологічного профілю у Львівській області у 2015 р. передбачалося у розмірі 56 160,8 тис. грн зі співвідношенням між зазначеними джерелами - 5,7 : 1,8: 1 [5].

В інших областях ситуація з фінансуванням гемодіалізу за даними повідомлень у відкритій мережі була дещо іншою. Так, за даними прес-служби Кабміну, на 2014 р. Київською міськдержадміністрацією було затверджено бюджет для 502-х пацієнтів для гемодіалізу та перитонеального діалізу на суму 62,4 млн грн. Окрім цього, у м. Києві зараз проживає 18 хворих 3 числа тимчасово переміщених осіб, які потребують гемодіалізу. В інших регіонах таких пацієнтів більше. Для їх забезпечення уряд у 2015 р. виділив додатково 1,4 млн грн $з$ держбюджету [13].

Харківська ОДА у квітні 2015 р. скоригувала витрати: 12 млн грн спрямувала на придбання витратних матеріалів для гемо- та перитонеального діалізу у комунальному закладі «Обласний клінічний центр урології та нефрології імені В. І. Шаповала» [14]. А станом на 01.12.2015 р. у ньому на постійному діалізі знаходилось 234 особи, з яких семеро - приїхали 3 Донбасу.

За інфрормацією комісії з охорони здоров'я одеської мерії у річний бюджет Одеси на ЛЗ закладено
80 млн грн, 3 яких близько 220 тис. грн на рік витрачають на 1 хворого, якому потрібен гемодіаліз, 150 тис. грн - на ліки 1 хворому 3 пересадженими нирками. Тобто, 40 млн. грн на рік йде на 300400 одеситів, решта 40 млн грн - на 1 млн населення (40 грн на одну особу) [15].

Відповіді на запитання: а яку терапію отримують пацієнти відділення хронодіалізу і хто є цими пацієнтами - стало ціллю наступного етапу роботи.

Розподіл 74-х медичних карток стаціонарних хворих на гостру і хронічну ниркову недостатність за статтю виявив домінування чоловіків над жінками (рис. 1, а). Найбільша кількість хворих була у вікових межах 30-39 і 60-69 років (рис. 1, б), які в основному проживали у сільській місцевості (66 \%).

Аналіз соціального статусу пацієнтів виявив, що 32 \% з них безробітні, 28 \% - інваліди; 16 \% - пенсіонери, по $11 \%$ - робітники і службовці (рис. 2).

У подальшому проведено дифреренціацію медичних карток за основними діагнозами захворювання пацієнтів та методами лікування (рис. 3).

Як свідчать дані таблиці 1, хворим на XXH найчастіше призначали препарат кальцію карбонату (Елітфарм, Україна) (11,88 \%), що відповідає Протоколу $[4,10]$. Для корекції гіпокальціємії пацієнти приймали по 0,5 г кальцію карбонату 3 рази на день під час їжі. Також відповідно до Протоколів хворі отримували вітаміни групи Д: Аквадетрим (Medana Pharma, Польща) і Ергокальциферол (Вітаміни ОАО, Україна) (по 3,96 \%) і препарати заліза: Сорбіфер Дурулес (EGIS Pharmaceuticals PLC, Угорщина) (4,95\%), ФерролекЗдоров'я (Здоров'я, Україна) (3,96 \%) і Тардиорерон (Euromedex, Франція) (2,97\%).

Хворі на XXH V стадії мають ускладнення основного діагнозу: порушення фоссрорно-кальцієвого обміну, анемію, цукровий діабет, серцево-судинні хвороби. Тому, окрім терапії згідно з Протоколам, їм було призначено лікування супутніх захворювань, що випливає $з$ проведеного аналізу препаратів за АTCкласифікаційними групами (рис. 4).
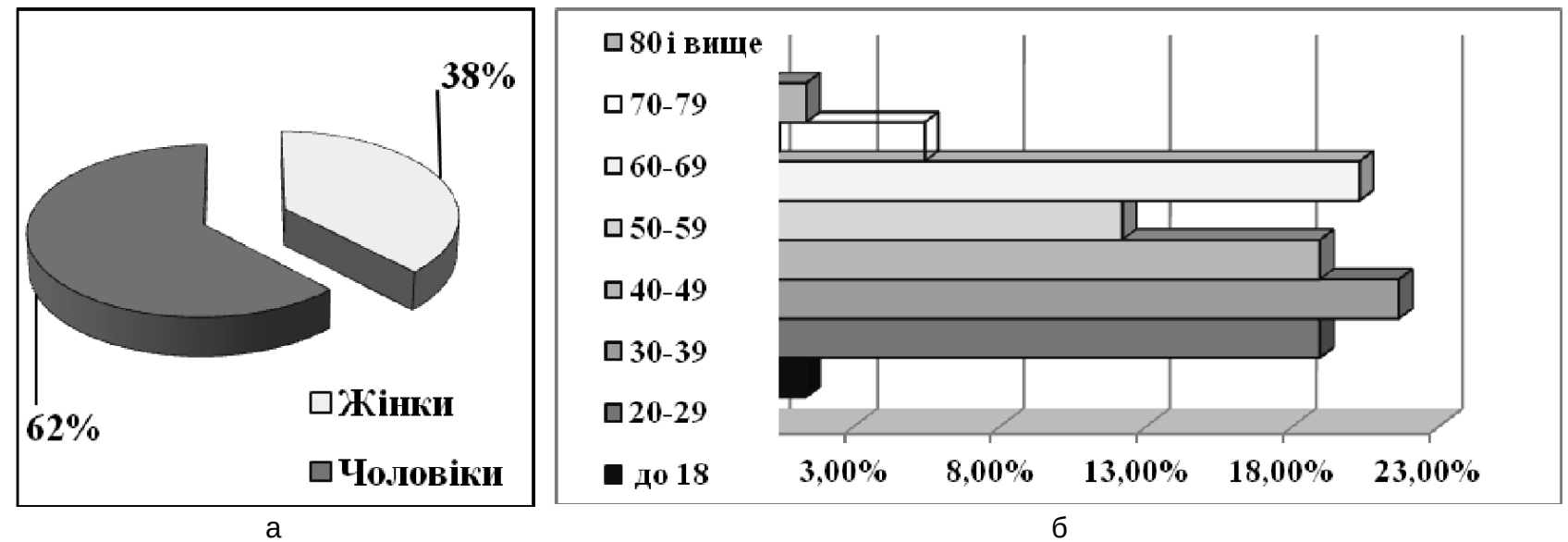

Рис. 1. Гендерний (а) та віковий (б) розподіл пацієнтів.

ISSN 2312-0967. Фармацевтичний часопис. 2015. № 4 


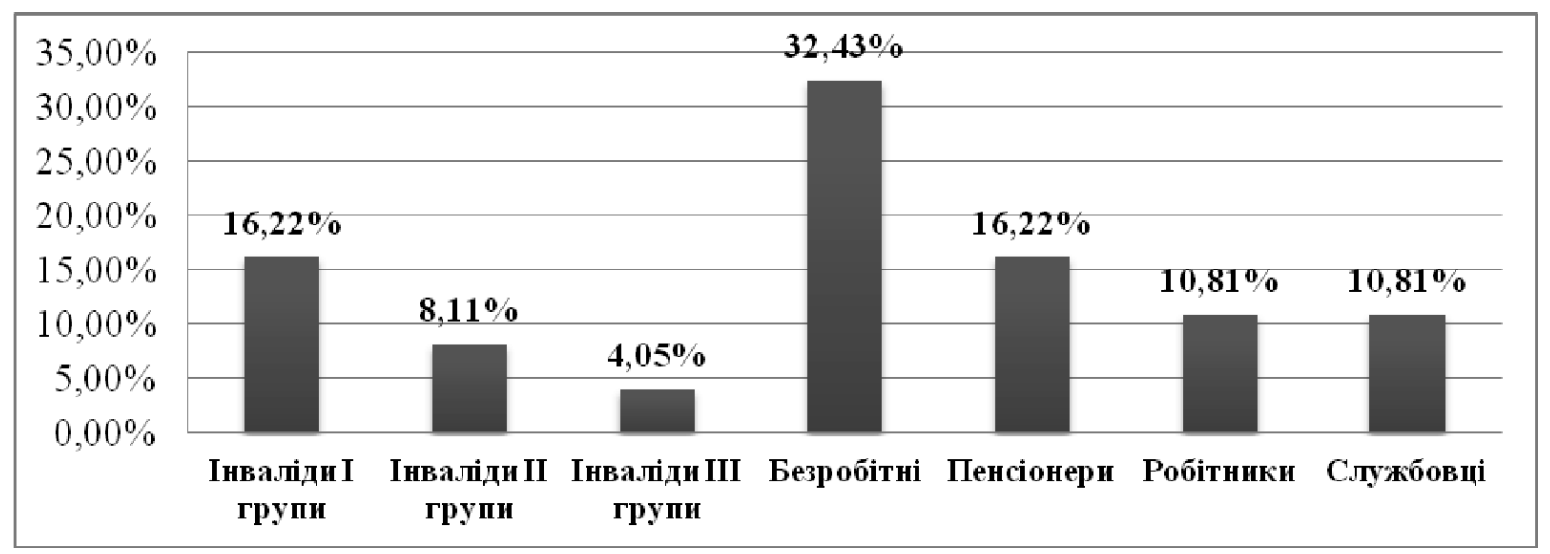

Рис. 2. Розподіл 74-х медичних карток пацієнтів за соціальним статусом.

I група - пацієнти, які хворіли на хронічну хворобу нирок (XXH) V стадії, кореговану програмним гемодіалізом, і яким була проведена операція артеріо-венозного шунтування зліва в нижній третині передпліччя - 17 \%.

II група - пацієнти з XXH V стадії, яких лікували медикаментозно і методом перитонеального діалізу - 8 \%.

III група - пацієнти 3 гострим пошкодженням нирок, яким було проведено

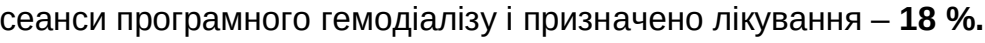

IV група - пацієнти 3 XXH V стадії, яким було призначено сеанси гемодіалізу і медикаментозне лікування - 22 \%.

V група - пацієнти 3 гострою нирковою недостатністю, яким було назначене тільки медикаментозне лікування - 35 \%.

Рис. 3. Розподіл медичних карток пацієнтів відділення хронодіалізу за встановленими діагнозами та методами лікування.

Таблиця 1. ТОР-10 препаратів, які найчастіше отримували хворі на XXH V ст.

\begin{tabular}{|c|c|c|c|}
\hline № & Назва препарату & $\begin{array}{c}\text { Абсолютна } \\
\text { кількість } \\
\text { призначень }\end{array}$ & $\begin{array}{c}\text { Частка } \\
\text { призначень }\end{array}$ \\
\hline 1 & Кальцій карбонат, табл. 0,5 г, № 100 (Еліт-срарм, Україна) & 12 & $11,88 \%$ \\
\hline 2 & Йогурт, капс., № 30 (Pharmascience, Канада) & 7 & 6,93 \\
\hline 3 & Сорбіфрер Дурулес, табл., № 30 (Egis, Угорщина) & 5 & 4,95 \\
\hline 4 & $\begin{array}{l}\text { Аквадетрим, p-н д/перорал. зас. водн. } 15000 \text { МО / мл фрл. } 10 \text { мл } \\
\text { (Medana Pharma S. А., Польща) }\end{array}$ & 4 & 3,96 \\
\hline 5 & Діакордин, табл. 60 мг, №50 (Zentiva, Чехія) & 4 & 3,96 \\
\hline 6 & $\begin{array}{l}\text { Ергокальциферол, р-н олійн. перорал. 1,25 мг / мл фрл. } 10 \text { мл, № } 1 \\
\text { (Вітаміни ОАО, Україна) }\end{array}$ & 4 & 3,96 \\
\hline 7 & $\begin{array}{l}\text { Ферролек-Здоров'я, р-н д / ін. } 50 \text { мг / мл амп. } 2 \text { мл, № } 5 \text { (Здоров’я, } \\
\text { Україна) }\end{array}$ & 4 & 3,96 \\
\hline 8 & $\begin{array}{l}\text { Дексалгін, р-н д / ін. } 50 \text { мг / } 2 \text { мл амп. } 2 \text { мл, № } 5 \text { (Menarini International, } \\
\text { Люксембург) }\end{array}$ & 3 & 2,97 \\
\hline 9 & $\begin{array}{l}\text { Кордарон, табл. } 200 \text { мг блістер, № } 30 \text { (Sanofi Winthrop Industria, } \\
\text { Франція) }\end{array}$ & 3 & 2,97 \\
\hline 10 & $\begin{array}{l}\text { Тардиферон, табл. пролонг., п / цукр. обол. } 80 \text { мг, № } 30 \text { (Euromedex, } \\
\text { Франція) }\end{array}$ & 3 & 2,97 \\
\hline
\end{tabular}

ISSN 2312-0967. Pharmaceutical review. 2015. № 4 
За результатами дослідження, загальна вартість спожитої фрармакотерапії хворими, які лікувалися у відділені хронодіалізу методами гемодіалізу і перитонеального діалізу, становила станом на 01.01.2014 p. 7 461,29, а на 01.07.2015 р. - 26 114,52 (на одного пацієнта 310,89 грн та 1 088,11 грн відповідно). Методом ABC-аналізу препарати, які отримали пацієнти, були розділені на 3 групи за вартістю. До найвитратнішої групи А (80 \% вартості терапії) увійшли 16 Л3, частка яких в загальній сукупності становила $30,77 \%$. Очолили групу А антибіотик Ванкоміцинтева 1000 мг фрл. № 1 (Teva, Угорщина) та блокатор Н2-рецепторів Разол-20 пор. ліоф. для приг. р-ну для ін. по 20 мг у фрл. № 10 (Байодженікс (Індія) Лімітед, Індія), які належали до препаратів для лікування супутніх хвороб. До групи В (15\% вартості терапії) увійшло 13 л3 (25\% із загальної сукупності Л3). Групу С (5 \% витрат) сорормували 23 Л3, що склало 44,23 \% від усіх препаратів.

На наступному етапі KEA було здійснено VENрозподіл препаратів. До класу $\mathrm{V}$ (найважливіші) було віднесено 12 л3, які рекомендовані Протоколами для терапії ускладнень XXH V стадії з найбільш несприятливими прогнозами (анемія, артеріальна гіпертензія, порушення фосфорно-кальцієвого обміну) [9, 10, 16, 17]: Аквадетрим (Medana
Pharma S.A., Польща), Берліприл (Berlin-Chemie AG, Німеччина), Венофер (Vifor (International) Inc., Швейцарія), Гемакс (Вio Sidus, Аргентина), Еналаприл (Здоров'я, Україна), Еповітан (Фармак, Україна), Ергокальциферол (Вітаміни ОАО, Україна), Кальцій карбонат (Еліт-фрарм, Україна), Сорбіфер Дурулес (Egis Pharmaceuticals PLC, Угорщина), Тapдисрерон (Euromedex, Франція), Ферролек-Здоров'я (Здоров'я, Україна) і Фозікард (BalkanpharmaDupnitza AD, Болгарія). До групи E (необхідні) нами були віднесені 6 препаратів для лікування артеріальної гіпертензії, які однак не ввійшли до згаданих Протоколів лікування. Групу N сорормувала решта другорядних препаратів (34 Л3), які призначали для лікування супутніх захворювань. Водночас сукупна вартість другорядних препаратів була найбільшою і становила 62 \% витрат спожитої фрармакотерапії (рис. 5). У групі А за витратами препаратів з індекcom $\mathrm{V}$ було 5, які склали 35 \% вартості групи, решта коштів (65\%) припала на препарати із індексом N. У групі А не було препаратів класу Е. Співвідношення раціональності витрат ( $\mathrm{V}: \mathrm{E}: \mathrm{N})$ у групі В можна представити як $38 \%: 19 \%: 43 \%$, натомість у групі С воно було - $34 \%: 12,5 \%: 53,5 \%$.

Отже, за результатами сумісного ABC/VENаналізів виявлено, що найвища частка витрат на

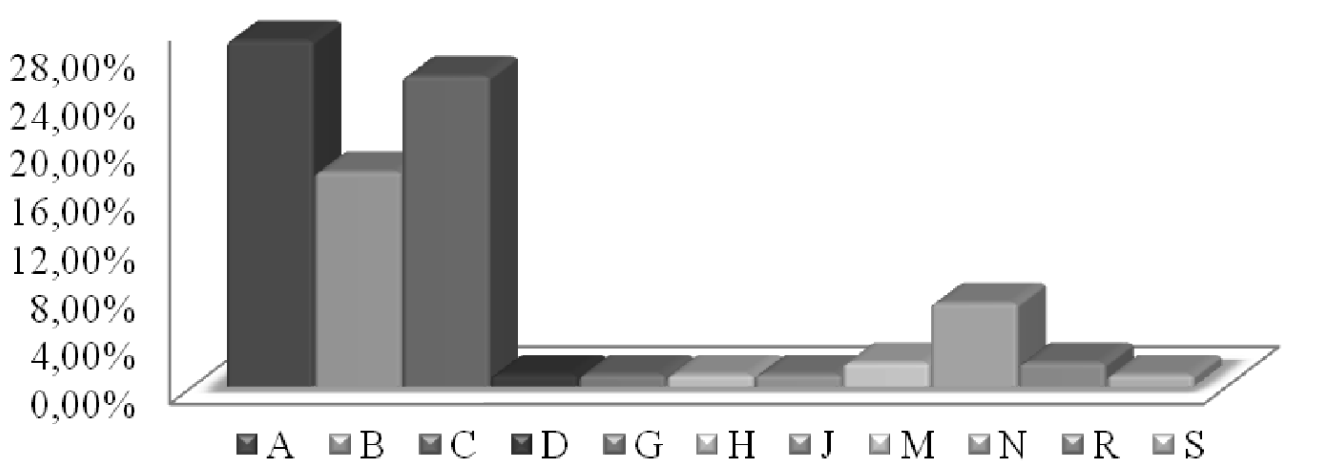

Рис. 4. Класифікація препаратів, спожитих хворими на XXH за АТС-класифікаційними групами.

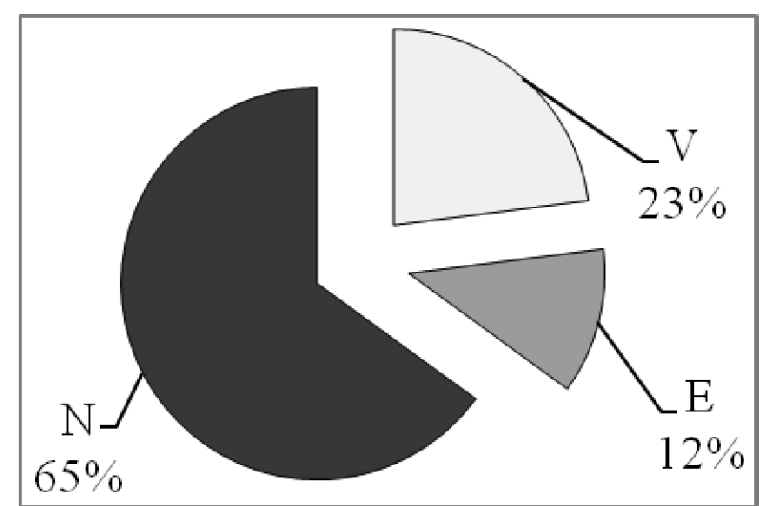

a

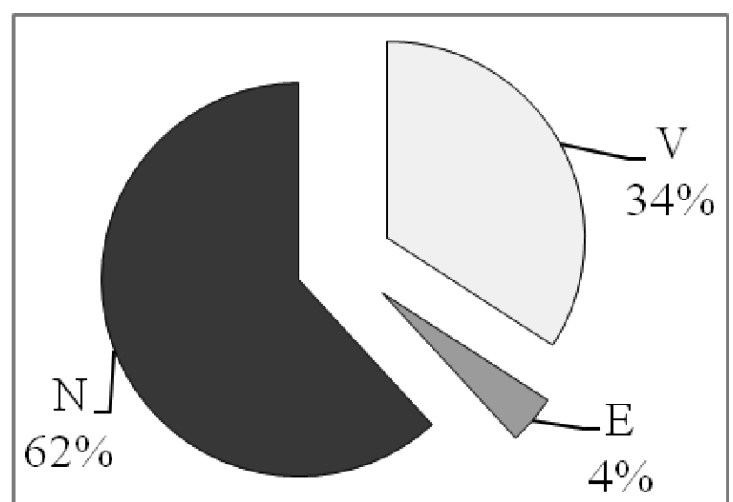

6

Рис. 5. Результати VEN-аналізу: співвідношення груп за часткою Лз (а) та витрат (б).

ISSN 2312-0967. Фармацевтичний часопис. 2015. № 4 
проведену фрармакотерапію припала на ЛЗ групи N (62 \%), що потребує перегляду та корекції.

Висновки. 1. Встановлено, що комплекс проблем, пов'язаних із лікуванням хвороб нирок, не втрачає актуальності як в Україні, так і в усьому світі. Це насамперед пов'язано 3 їх прогресуючим перебігом, поступовим зниженням функцій нирок і необхідністю застосування високовартісної замісної терапії.

2. Івано-Франківська область займає передові позиції в державі щодо лікування хворих замісними методами ниркової терапії та за рейтинговими показниками посідає перше місце. Фінансове забезпечення регіональної програми «Здоров'я населення Прикарпаття на 2013-2020 роки» за останні 3 роки задовольняє потребу у гемодіалізі 327-391 пацієнтів. Але лікарські препарати пацієнти змушені придбавати за власний кошт. Однак хворі на хронічну хворобу нирок, як показало дослідження, переважно належать до соціально неблагополуч- них і малозабезпечених верств суспільства, тому, крім гемодіалізу, їм потрібна державна допомога і на ліки.

3. За результатами аналізу гендерних, вікових, соціальних характеристик хворих встановлено, що на гостру і хронічну ниркову недостатність хворіють як жінки, так і чоловіки віком від 18 до 80 років. В основному це інваліди і безробітні, які переважно проживали у сільській місцевості.

4. Результати ретроспективного клінікоекономічного аналізу фрармакотерапії, яку спожили хворі, свідчать, що вони, окрім сеансів програмного гемодіалізу і перитонеального діалізу, отримали лікування для запобігання частих ускладнень хронічної хвороби нирок (35 \% призначених препаратів за найменуваннями та 38 \% сумарної вартості терапії) та лікування супутніх хвороб (65 \% лз за найменуваннями та 62 \% вартості терапії), що потребує корекції відповідно до вимог фрормулярного підходу.

\section{Список літератури}

1. Про поліпшення якості та організації системи медичної допомоги дорослим хворим нефрологічного профрілю: наказ МО3 України від 30.09.2003 р. № 65 / 462 [Електронний ресурс]. - Режим доступу : https:// moz.gov.ua/ua/portal/dn_20030930_462.html.

2. Медико-профрілактична допомога хворим нефрологічного профрілю 2009-2012, що робити далі? [Текст] / М. О. Колесник, Н. О. Сайдакова, Н. І. Козлюк, С. С. Ніколаєнко // Український журнал нефрології діалізу. - 2013. - № 3. - С. 3-14.

3. Перитонеальний діаліз та гемодіаліз у лікуванні хворих 3 хронічною нирковою недостатністю [Текст] / [М. О. Колесник, І. О. Дудар, Ю. І. Гончар та ін.] // Методичні рекомендації. Київ. - 2003. - 43 с.

4. Колесник М. О. Стандарти нефрологічної допомоги: клінічна настанова, медичний стандарт та протоколи лікування методом гемодіалізу [Текст] / за редакцією профресора М. О. Колесника // Довідник лікаря «Несролог»-К. : ТОВ «Доктор-Медіа», 2011. - 180 с.

5. Регіональна програма надання медичної допомоги хворим нефрологічного профілю у Львівській області, 2015 [Електронний ресурс]. - Режим доступу: www. oblrada.lviv.ua/.../1315.doc.

6. Яковлева О. С. Дослідження стан фрінансування фрармацевтичного забезпечення хворих на хронічну ниркову недостатність у світі та в Україні [Текст] / О. С. Яковлева // Формування Національної ліка́рської політики за умов впровадження медичного страхування: питання освіти, теорії та практики: III Всеукр. наук.-практ. конфр., 12 бер. 2015 р. : матеріали конф. - Харків: Вид-во НФаУ, 2015. - С. 72-81.

7. Протокол лікування пацієнтів 3 хронічною хворобою нирок $\vee$ стадії: діагностика стану та корекція порушень фросфорно-кальцієвого обміну у хворих, які лікуються методом гемодіалізу [Текст] / М. О. Колесник, К. М. Законь, М. В. Кулизький [та ін.] // Український

журнал нефрології і діалізу. - 2010. - № 2. - С. 39-42.

8. Протокол лікування пацієнтів з хронічною хворобою нирок V стадії: лікування анемії [Текст] / М.О.Колесник, К. М. Законь, М. В. Кулизький [та ін.] // Український журнал нефрології і діалізу. - 2010. - № 2 - С. 29-38.

9. Національний реєстр хворих на хронічну хворобу нирок : 2012 рік [Текст] / уклад. Н. І. Козлюк, С. С. Ніколаєнко, М. В. Кулизький; Державна установа «Інститут нефрології НАМН України»; гол. ред. М. О. Колесник. - К., 2013. - 89 с.

10. Медико-демографічна ситуація та основні показники медичної допомоги населенню в регіональному аспекті 2013 рік - Київ, 2014 - 168 с. [Електронний ресурс]. - Режим доступу : http://www.uiph.kiev.ua/dawnload/ Vidavnictvo/ Medikodemografichna\%20situacia.\%202013.pdf.

11. Обласна влада залучила ще 14 млн грн на гемодіаліз до кінця року [Електронний ресурс]. - Режим доступу : http://www.if.gov.ua/news/24800.

12. Особливості бюджету Прикарпаття на 2015 рік [Електронний ресурс]. - Режим доступу : http://paralleli. if.ua/news/49884.html.

13. Вступне слово Прем'єр-міністра України Арсенія Яценюка на засіданні Уряду України 19.11.2014 р. [Електронний ресурс]. - Режим доступу : http://www.kmu. gov.ua/ control/publish/article?art id=247762308.

14. Харьковские врачи бьют тревогу [Електронний ресурс]. - Режим доступу : http://gx.net.ua/region/ harkovskih-medikov-ostavili-bez-finansirovaniya-.html.

15. В Одессе половину всего бюджета на медикаменты выделяют для 300 горожан [Електронний ресурс]. - Режим доступу : http://www.reporter.com.ua/news/ pсp590/.

16. Лікування анемії у хворих з хронічною нирковою недостатністю [Текст] / М. О. Колесник, І. О. Дудар, Ю. І. Гончар [та ін.] // Методичні рекомендації. Київ. 2003. -22 c

ISSN 2312-0967. Pharmaceutical review. 2015. № 4 
17. Єршова А. К. Етіологія, патогенез та лікування залізодефіцитної анемії [Текст] / А. К. Єршова // МЖ.
Клінічні рекомендації та алгоритми для практикуючих лікарів. - 2009. - Т.19, № 12. - С. 790-794.

\title{
КЛИНИКО-ЭКОНОМИЧЕСКИЙ АНАЛИЗ ЗАМЕСТИТЕЛЬНОЙ И ФАРМАКОТЕРАПИИ БОЛЬНЫХ ХРОНИЧЕСКОЙ БОЛЕЗНЬЮ ПОЧЕК V СТАДИИ
}

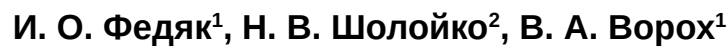

${ }^{1}$ Ивано-Франковский национальный медицинский университет

${ }^{2}$ Национальный медицинский университет имени А. А. Богомольца

\begin{abstract}
Резюме: рассмотрено проблему фринансирования гемодиализа для больных в Украине и представлены количественные показатели ее решения в Ивано-Франковской области - регионе, который является лидером рейтинга по лечению больных заместительной методами почечной терапии. Кроме того, представлены результаты ретроспективного клинико-экономического анализа сопутствующей фрармакотерапии больных хронической почечной недостаточностью, находящихся в отделении хронодиализа Областной клинической больницы г. ИваноФранковска. По данным исследования, пациенты, кроме сеансов гемодиализа и перитонеального диализа, получили медикаментозное лечение осложнений хронической болезни почек (анемии, артериальной гипертензии, нарушения фросфрорно-кальциевого обмена), а также лечение сопутствующих болезней, что требует коррекции относительно соответствия требованиям Клинических протоколов.
\end{abstract}

Ключевые слова: хроническая болезнь почек, финансирование гемодиализа, клинико-экономический анализ.

\section{CLINICAL AND ECONOMIC ANALYSIS OF CONCOMITANT AND PHARMACOTHERAPY OF PATIENTS WITH CHRONIC KINDEY DISEASE OF V STAGE}

\section{O. Fedyak ${ }^{1}$, N. V. Sholoyko ${ }^{2}$, V. O. Vorokh ${ }^{1}$}

${ }^{1}$ Ivano-Frankivsk National Medical University

${ }^{2}$ National Medical University by O. O. Bohomolets

Summary: the article presents the problem of hemodialysis financing for the patients in Ukraine and quantitative indicators of its solving in Ivano-Frankivsk region, which is the leader of the rating on the treatment of patients by substitution methods of renal therapy. In addition, it is showed the results of a retrospective comprehensive clinical and economic analysis of concomitant pharmacotherapy of patients with chronic renal failure who were treated at the hemodialysis department of Ivano-Frankivsk Regional Clinical Hospital. According to the results of the research, patients in addition to sessions of hemodialysis and peritoneal dialysis received medicaments against complications of chronic kidney disease (anemia, hypertension, disorders of calcium and phosphorus metabolism), as well as treatment of concomitant diseases, which needs the correction in accordance with the Clinical protocols requirements.

Key words: chronic kidney disease, hemodialysis financing, clinical and economic analysis. 